\title{
PEDAGOGICAL USABILITY: A THEORETICAL ESSAY FOR E-LEARNING
}

\author{
F. M. SALES JÚNIOR ${ }^{1 *}$, M. A. S. RAMOS ${ }^{2}$, A. L. S. PINHO ${ }^{3}$ and J. G. SANTA ROSA ${ }^{3}$ \\ ${ }^{1}$ Instituto Federal de Educação, Ciência e Tecnologia do Rio Grande do Norte (IFRN) \\ ${ }^{2}$ Universidade do Minho - Portugal \\ ${ }^{3}$ Universidade Federal do Rio Grande do Norte (UFRN) \\ monteiro.junior@ifrn.edu.br*
}

Article submitted in November/2014 and accepted in December/2015

DOI: $10.15628 /$ holos.2016.2593

\begin{abstract}
The e-learning in Brazil has shown such intense development followed by its problems. Obstacles in the teaching learning permeate, among others, the use of virtual environments, production of teaching materials, pedagogical mediation, where the tutor has responsibility in these factors. In order to combine the
\end{abstract}

use of technology with the nature of the pedagogical dimension, this theoretical essay discusses the concept of pedagogical usability from existing problems and presents explanations about the dimensions and criteria present in the literature.

KEYWORDS: Virtual learning environment, education, Moodle, educational technologies.

\section{USABILIDADE PEDAGÓGICA: UM ENSAIO TEÓRICO PARA O ENSINO A DISTÂNCIA}

\section{RESUMO}

O Ensino a Distância no Brasil tem apresentado um crescimento tão intenso quanto os problemas que o acompanham. Os entraves no processo ensinoaprendizagem permeiam, dentre outros, o uso dos ambientes virtuais, a produção de material didático e a mediação pedagógica, tendo o professor particular responsabilidade nestes fatores. Com a finalidade de aliar o uso das tecnologias com a essencialidade da dimensão pedagógica, este ensaio teórico discute o conceito de usabilidade pedagógica a partir dos problemas existentes e apresenta explicações sobre as dimensões e critérios presentes na literatura.

PALAVRAS-CHAVE: Ambiente virtual de aprendizagem, educação, Moodle, tecnologias educativas. 


\section{INTRODUCTION}

E-learning $(\mathrm{EaD})$ in Brazil has shown a strong development, and is occupying gaps that the presence-based course modality did not fill. Since the 1990s, public policies for the expansion of education networks, and digital inclusion, include and normalize this modality, adjusting the EaD intentions as an e-learning that enables the self-learning, by mediation of didactic resources systematically organized (BRASIL, 1998). Afterwards, e-learning was characterized as the educational modality in which the didactical-pedagogical mediation, in teaching and learning processes, occur with the use of information and communication technologies, with teachers and students developing educational activities in different places or times (BRASIL, 2005). In recent years, the development of public power was even of greater extent, increasing the number of institutions, classroom support centers, telecenters, laboratories, teachers, and tutors who work with e-learning.

Along with the investment, a huge amount of problems was plotted in a rising exponential curve, inherent to the process, and are explicit from high dropout rate and a continuous questioning on the quality of results. However noble the intention of expansion, in the disorderly race of the institutions to be in the "virtual world", without observe basic assumptions when implementing platforms, a number of issues had problems during operation and management of teaching-learning process in public schools. Obstacles take different dimensions and pass, among others, by computing infrastructure, by the use of learning objects and mediation tools. The production of educational and instructional material had different authors presenting considerations and guidance, so that the text provides the ease of reading, and the continuous recovery of used contents.

However, it is still observed the availability in the scan platforms of pieces of printed media. With regard to the availability and maintenance of information in educational environments, the literature recommends the accessibility and usability principles, in order to ease and intuitively found it, enabling the student to explore the diverse levels without difficulties. This procedure was facilitated with the advent of content management systems (BOIKO, 2004), and with Web 2.0, enabling the publication and the management of information, regardless the specialized technical crew. However, text and files are kept outdated and disorganized in virtual classrooms, which is considered the most inadequate and recurrent practices. Moodle (Modular Object Oriented Distance Learning) is a virtual learning environment used in public institutions in Brazil, being a reliable, configurable platform of recognized quality, and aligned with internationally recommended standards (SALES JÚNIOR et al, 2015a).

However, the inherent resources that can enhance the learning are underused. The main obstacle of the process is primary. The platforms are used inappropriately due to sufferable pedagogical approaches. This issue goes definitely by the teacher's responsibility. The teacher, participant and responsible for interaction processes, is essential in this educational modality. In addition, if they do not work well, all learning is compromised, and the virtual platform turns into a cold and empty classroom, which, in fact, is already observed in different courses. Normally, the teachers justify their own absences by outsourcing many of its responsibilities to the tutors. In addition, on behalf of the autonomy rhetoric, and highlighting what they understand as 'selflearning', they blame the students in case of dropout. Their practices in a virtual environment permeate the unidirectional availability of materials, sometimes reused from classroom or 
elaborated without observing the simplification of the language, and solid principles of usability (OLIVEIRA, 2004), as if the digital technologies were enough to the success of the course. Thus, it is observed that the attitudes and procedures of the teachers constantly point to reactive pedagogical mediation practices, not promoting interactivity in the learning. The student collaboration is utilized as a possibility of authorship, and an orthogonal position is used rescuing and replicating the traditional models. Excluding the inherence of online processes, and training ambiences elements, like a complex subjective entanglement that dynamizes from diverse possibilities of interaction, intellectual production, management, and creation of collections (BELINTANE, 2002), the student remains solitary in their doubts and questions.

The emphasis on operational and instrumental, with no care to mediation, interactivity, and innovation in pedagogical methods (SALES JÚNIOR et al, 2015b) promote motivation, and therefore dropout. In this context, although the educational technologies have an active role, and a co-structure way to learn and knowing (ASSMANN, 2005), it is observed that it is only succeed when aligned to the demands and pedagogical strategies. It is observe that the technologies have been used timidly by teachers, or understood as enough in the process, transferring to the student the responsibility of their low utilization and discontinuity. Although, there is evidence of the lack of teacher training in some cases, we do not ignore the accommodation, lack of interest, and commitment of others.

Confronting these facts, this study aims to present and discuss a recent concept in education called 'pedagogical usability', which deals with the environment construction, preparation of materials, and mediation strategies. The dimensions of this theme can be implemented in the context of virtual learning environments, combining the facilities and resources of technologies with the essentiality of the pedagogical greatness. The teacher has a key role as a mediator, intermediator, and consultant in the adoption of new methods of teaching and learning, with support of educational technologies such as those utilized in EaD, within the context of innovative educational models.

\section{PEDAGOGICAL USABILITY:}

The term usability is defined as the ability of a product to be used by specific users to achieve specific goals with effectiveness, efficiency, and satisfaction, in a specific context of use (ISO, 1998). The concept (generic) deal with the facility (or quality) of use, and shall not be neglected, prevent the risk of frustrating the users expectations, which is essential in the educational environment. Castells (2000) states that in the virtual world, the usability refers to the ease of using a hypermedia system, defined as a combination of languages that became part of the history of humanity, such as the writing, the sound, and the image, in the same interactive communication system, being shared on a wide, global, and simultaneous scale. Usability has a component called 'technical' or 'design' (REITZ, 2009), that addresses the web context and permeates the planning and implementation proper to systems and virtual environments. The essence of literature in design usability area, reinforces the implication that, if a virtual interface is properly designed and managed, with a high usability level, its users will learn easily to use it, and they will be pleased to have their needs supplied. Different authors relate usability issues with user satisfaction, in a direct or indirect way. Therefore, assume that by visiting a virtual page, the users present a set of expectations, anxieties, and needs that shall be removed, or satisfied. In fact, 
according to Ulbricht (2014), the usability is linked to efficiency, which leads to the understanding of the content, in order to make the users autonomous and sufficient in their surfing in the web, without requiring any support, help, or external action to perform the task. These environments need to be linked with the expectations of users, who in educational environment are students. Interfaces that is unsettled, polluted, full of materials, disorganized, and out of standards and conventions make students give up of interaction.

A second implication is the fact that, facing difficulties offered by virtual environments, the students tend to blame themselves for that. Although the real obstacles are in the interface or in the absence of pedagogical guidelines, this behavior is commonly observed in students who use virtual classrooms, and who have lack of knowledge base in information technology. At other extreme, when the users surf without obstacles, they are satisfied and show interest to return. The virtual learning environment shall have a clear visual hierarchy, and be clear enough to avoid doubts or concerns in the student. If they need to decipher aspects that do not matter, they will tend to waste energy and enthusiasm. Dropout in online courses also occurs due this fact. Design usability principles shall be observed in e-learning context to support the teaching-learning process, and contribute in static and dynamic structures to the proper management of electronic content.

On the other hand, despite of numerous new tools of collaboration aggregated in virtual learning environments, routines and processes related to pedagogical aspects may still be unstructured, providing a low level of learning. Depending on the level of virtual services provided, the initiatives and emerging technologies for e-learning do not guarantee the students learning. The lack of compliance with pedagogical guidelines implies in loss of the goal, which is essentially the learning. Many troubles highlight the need for a better management of existing technological resources, and standardization of processes and workflows to align them with educational goals, requiring continuous interactions. At this conjuncture, it is necessary the explanation of a concept in education considered emergent and innovative to some authors, although their bases are replicated or adjusted in different areas of knowledge, including the human-computer interaction, and interaction design: the pedagogical usability.

Considering the text of ISO 9241-11, it is understood that the pedagogical usability can be evaluated in the context of educational environment, occasion in which the content is consumed by specific students, who wish to achieve specific educational purposes, effectively and efficiently, and getting satisfaction in their learning. Therefore, the pedagogical usability is studied when it returns to a teaching environment. In case the interaction between students and systems that utilize technologies occurs only for a unidirectional transmission of instructions, the existing artifacts available to fundamentally change the conceptions, and the teaching-learning methods will be underutilized.

Although the numbers show an increase of publications related to e-learning, Matos (2013) states that studies on the pedagogical usability are reduced and restricted, due to the limited use of digital materials at school. In fact, new investigations are necessary, involving different usability evaluation techniques related to pedagogical issues. The term 'pedagogical usability' was first presented by Nielsen (1990) when presenting his conceptual map about usability, although without deep knowledge, and has been the target of new and recent investigations and reflections. Silius and Tervakari (2003) use the term to question whether the tools, content, interface, and tasks of environments based on the web, meet the learning needs of different students, in many 
contexts, according to the specified educational goals. There are diverse ways to implement and assess the requirements of pedagogical usability, which usability test is one of them. VetromilleCastro (2003) states that a huge part of usability test in the computer area is superficial when balanced the orientation level that the user encounters. The author alleges that the pedagogical usability is more restricted compared with the proposed activity, and that the educational materials shall be developed according to the student. It is observed that the emphasis needs to be on what deals with the pedagogical preparation, so that all actions shall point to the main purpose, whereas a low pedagogical usability affect the learning processes (VETROMILLE-CASTRO, 2003). An author observation is that the pedagogical usability is consolidated through the feedback provided to the student, considering the importance of the moment and the kind of activity proposed, among other pedagogical aspects that constitute this bias. Indeed, the pedagogical usability focuses on providing feedback and reading strategies as one of its main attributes.

Nokelainen (2004) considers that the pedagogical usability of a system, and/ or learning materials is also dependent on goals set by the student and the teacher in a learning situation. Then, considering the expressiveness and contribution to knowledge in question, Nokelainen (2006) presented ten dimensions of pedagogical usability regard to teaching strategies and environment preparation to be observed in an application dedicated to teaching, which is already adapted to this context. The dimensions are composed by different criteria obtained from empirical studies related to the evaluation of digital educational materials, and learning management system measuring. Although it can be adopted in other fields and methods, as virtual learning environments.

Martins (2009) emphasizes the importance of feedback to the student, ensuring that when it comes at the right time; can provide greater interaction between the authors in the teachinglearning process. The author tried to relate the different ways used for student learning. Different learning styles shall be considered when conceive designs that permeate the design usability and the pedagogical usability, directing the attention to the student, and considering the bias of their skills and expertise for the management of a digital environment focused on learning. Therefore, we present two aspects of the evaluation that needs to be performed, to observe if the system will promote the desired success: the design usability test, also called technical usability test; and pedagogical usability test. The first evaluate the choices and technological quality of educational environments; the second evaluate whether the didactic and methodological choices by the developers of proposed tasks, favoring the student learning (MARTINS, 2009). Agner (2009) states that, pedagogical usability can involve the study of more advanced issues of educational theories, and has a successful experience in evaluation research of usability, aiming to cooperate in the concept consolidation. The work demonstrated how the use of empirical methods of collection and analysis of data could contribute to improve the surfing design, focusing on the student. The research, based on collection of opinions, and organized by affinity diagrams, contributed to a greater adequacy of the course to the student's profile (AGNER, 2009). Reitz (2009) deals with the concept in the context of e-learning and toward, establish, and adapt criteria to the learning. Santa Rosa and Struchiner (2010) used a participative design approach in developing a virtual learning environment, structured according to the principles of ergonomics-pedagogy, in order to adapt it to teaching and learning needs. Oliveira (2011) addresses studies that associate the development of educational materials, and explain how the pedagogical preparation was conducted to promote the learning. 
According to Dias (2008), the pedagogical usability is inserted within the context of participative structures for innovation, creating a new knowledge in emerging scenarios of elearning by using educational technologies. The author states that the characteristics and demands of globalization process need to be observed in perspective of skills formation for inclusion, participation, and collaboration of a joint learning development. Years later, in contribution to thought about the pedagogical change in emerging scenarios of education and learning by Internet, Dias (2012) resumes the importance of adopting models and activities involving participation and collaborative mediation. The guidance is necessary for pedagogical change in the development of educational processes in relation to individual and collective participation, in communities of learning and knowledge (DIAS, 2012). The pedagogical usability concept is referenced in this context, where its adoption shall be performed in a consistent and practical manner, in emerging environment of open education, and in networking. The approach considers that the concept provides transformation and change from the social and cognitive mediation, for the sustainability of educational innovation. This is an alert for the need to adjust the methodologies to the new learning scenarios.

Sales Júnior and Ramos (2014) present an evaluation model of technical and pedagogical usability, in which the sample is divided into two groups of students submitted to two different and controlled scenarios, each one containing a virtual learning environment previously settled, as shown in Figure 1.

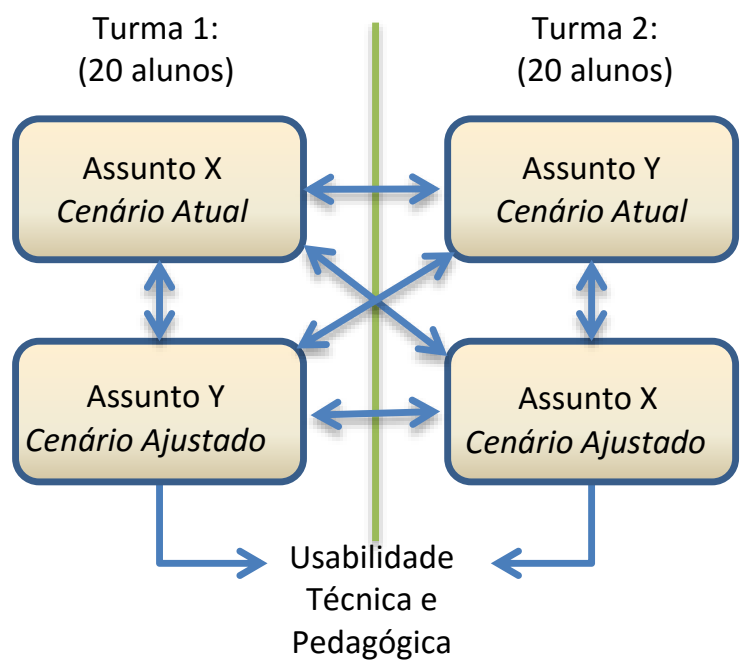

Figure 1 - Scheme of scenarios for evaluation of technical and pedagogical usability.

Source: (SALES JÚNIOR and RAMOS, 2014).

The first scenario showed the groups of students interacting in an environment of design and learning content, in the manner usually adopted, without observing criteria of pedagogical usability. The second scenario showed the same group interacting in a learning environment, settled to the dimensions of pedagogical usability, while the content (subjects) previously treated was inverted. Sales Júnior et al (2015b) implemented a model on a preliminary basis, in an empirical study, in a virtual environment of Moodle learning, e-learning modality, and found significant relevance in categories related to the cooperative and collaborative learning activities, activities in groups toward to problem solving, and feedback criteria, guidance and evaluation, according to Nokelainen (2006) and Reitz (2009). 
Thus, the pedagogical usability dimensions in e-learning are based on the premise that the students not only will have access to new digital technologies, but also to significant educational resources, in order to be positioned as participants of the process, demystifying the paradigm that they are mere consumers of unidirectional information issued by the teacher. The implementation context shall consider the student as creator of information, and direct collaborator of activities, whether sharing, connecting, or cooperating all the time, while considered a social subject moved by diverse stimulus. As the main protagonist in the process of teaching and learning, they rely on the interaction of their pairs. These processes occur from the wide-range activities offered by the teacher, who is the mediator with flexible planning, giving voice to the student, motivating their authorial nature, evaluating whether learning processes are adequate, and whether the offered time is enough for its purposes. This movement, shared with social authors in educational training, makes the student and teacher learn by doing, using critical-analytical interpretation, by constantly think, working together on different issues, in cooperative and collaborative actions.

\section{DIMENSIONS OF PEDAGOGICAL USABILITY}

Pedagogical usability dimensions can be adopted in virtual learning environments with wide coverage. Next, you will see the principles proposed by Nokelainen (2006), and reinforced or corroborated by different authors as Silius and Tervakari (2003), Ssemugabi (2006), Agner (2009), Martins (2009), Reitz (2009), Abreu (2010), Oliveira (2011), Sales Júnior and Ramos (2014), and Sales Júnior et al (2015b).

\section{Student Control}

The 'student control' dimension shows that the approaches (materials, dynamics, evaluations, ...) need to be designed in order to reach an appropriate level of overload of the student memory, estimated from five to nine items (short-term memories), varying from individual to individual. This principle is relevant whereas the human cognitive system can only process a limited amount of information. Learning occurs with greater fluidity when the consumption process of information is aligned to the student's cognitive process, maintaining a threshold of compatibility between the amount of content, and the individual understanding capacity. By disregarding the limit, the assimilation is no longer satisfactory and natural, showing a low performance, and overloading the cognitive structure (SWELLER, 2003). Thus, compliance with the principle implies in an increase of the capacity of human cognition process, where the student interaction is subjected to educational technology aligned to the learning process. Strategically, considering the subjective difficulties inherent to this identification, the teaching materials to be used shall be divided into meaningful units, structuring them in pieces, or units for better assimilation. This dimension also recommends that strategies shall be implemented by aggregating the student's responsibility to the process. In addition, the adopted technologies shall be under the student control (AGNER, 2009). The process of use and handling of both didactic resources and systems, settings and interactions, shall be preferably in the students domain, which will provide them greater learning and adaptation. In practical terms, a game or ludic activity, in virtual learning environment shall be fully implemented, with maximum resources as possible. A video, for example, shall be able to be seen and revised as necessary, if the student is the author responsible for limit setting. 


\subsection{Student Activity}

The 'student activity' dimension ponders aspects of teaching to be established by the teacher. They need to be structured in such a way that sounds interesting to the student, and hold their attention and action. Therefore, the scenarios can be developed, preferably, in a format that rescues aspects of real life. A possibility for dimension implementation is the use of strategies of games, and educational challenges, from the problems to be solved. Alternatively, consultation sources can be available, from which the student will develop their own concepts, considerations, and reflections, individually or in groups, to further exposure and fight with those produced by other students, where the teacher is the mediator. Accordingly, the establishment of a differentiated teaching provides the student engagement, so their individual activities will be increased and improved. Students shall be involved in goals and results, focusing on learning.

\subsection{Collaborative and cooperative learning}

The 'collaborative and cooperative learning' dimension provide strategies where the students study together to achieve a goal of shared learning. In cooperative learning, the focus is on the product to be generated, where the individual roles of the group members are structured in advance, although there is a possibility of renegotiation. The activities management is focused on the teacher, who gives instructions to students and conducts the mediation. In collaborative learning, the focus is on the process, with activities of the group members not structured, and their roles defined as long as the activity develops (SANTOS, 2008). The activities management is focused on the student, and the teacher does not define how to perform the group activities. This scenario corroborates with Agner (2009) study, when addressed that instead of acquiring personal knowledge, the students develop knowledge in practice, as members of a community. Within the e-learning, the systems, resources, and learning materials, based on the use of technologies and networks, are constituted in tools that can be used to communicate or negotiate, synchronously or asynchronously, different solutions for one question. Objects of learning or computer resources in virtual environment, can constitute tools for socialized surfing, in which the student gets information on what their pairs have done or are doing, which implies in common learning, and in a constructivist view. The criteria operationalization of this dimension, make the students more active in the learning process, reducing the inherent passivity to the traditional unidirectional system, in which the teacher is restricted to pass along the information. Small group's formation implies in higher favoring of the development of skills, whether intellectual or social, and the sharing of experiences favor the learning. Activities like glossary and wiki, native from Moodle, are aligned to this context.

\subsection{Guidance to purposes}

The 'guidance to purposes' dimension emphasizes the importance to develop activities from clear and specific purposes to be achieved, which the students shall be aware. The purposes can be abstract, concrete, or measurable (goals), in quantity compatible with the students level, and defined with their participation, whenever possible. Strategies prize the fact that the students became aware of the desired intents to be achieved with tasks, distinguishing the meanings of their efforts; besides have, the choice on their studies in relation to what is set. 


\subsection{Applicability}

The 'applicability' dimension recommends the use of approaches involving the alignment between the discussed subjects, and skills that will be required for professional or social life of the student, besides being related to other situations. Practices related to situations or authentic contexts, or that allows the students to learn by doing, or even leads him to use the skills and knowledge acquired in other contexts. Strategies, materials, content, and resources need to be sized in order to be in an appropriate level of the student's point of view, meeting their needs and subject to adjustments as necessary. Pedagogical practices, with the use and support of technologies, shall pass through continuous pedagogical evaluation to verify the level of difficulty found in the material, which is being an obstacle. Operationally, and in the context of e-learning, the actions permeate the checking to evaluate whether the activities are being performed, whether the time is compatible, whether the quantity of hits and misses performed by a student in some activity is out of step, facing the collection of information, and adjusting the procedures to return to the process. It is important, in some situations, the dialogue between the authors of the process (teachers and students) to refine the necessary settings. Teachers need to be aware and get ahead in the adaptation of scenarios that may bring difficulties to the students, such as the insert of a complex concept, the need for prior knowledge, or the structure requirements for execution of the proposed tasks. The essence of candle dimension by strategies development (ways to approach the content, production of material, ...) that correspond to the skills necessary, in a practical and applied way, in the student's life.

\subsection{Value-added}

The 'value-added' dimension appears when the resources, materials, and strategies used in digital learning add, in fact, value to the learning. This parameter can be measured, among others, from the comparison with other types of strategies (use of printed material, for example), whether in cooperative or individual learning approaches. Value-added in e-learning is often evident when the creativity is used by technological resources, from voice files, images, videos, and even activities involving animations, which allow interactions like games. Nokelainen (2006) studies present a list of computer-assisted learning aspects that provides value-added, such as adaptability to individual needs; number of options; learning controlled by the student, initiated by the student, and presented according to the student desire; interesting content; communication development; and active participation of students. The operationalization of the list of items require professionals with skills, experience, multidisciplinary expertise, time to develop, test, and validate the instructional material of the design, which in turn, shall be of relevance, attractiveness, and flexibility to engage the student, since it shall be aligned to their needs.

\subsection{Motivation}

The 'motivation' dimension pass through strategies, materials, approaches, and interactive tasks, which provides continuous motivation in students, full conditions for creativity, and new circumstances for learning. In e-learning, the criteria operationalization can be obtained from online activities focusing on real situations, simulated scenarios, case studies of occurred facts, or the need for positioning and decision making. Activities involving the motivation can start from 
different approaches, where those that promote critical-analytical thought are recommended for active learning. The motivation is critical fact for learning (AGNER, 2009).

\subsection{Value of prior knowledge}

The 'value of prior knowledge' dimension, respect the student knowledge from their experience of life, whether personal or professional, or even acquired through training in progress. Strategies use subjects previously worked, but related (or are essentials) to the knowledge taught at the time. In this case, the review or resume of topics already worked are possible alternatives. Individual differences, existing between students' skills, shall be identified and respected, and encouraged to make use of knowledge acquired as advantages for themselves, establishing relationships and linkages with the contents taught in the course or discipline.

\subsection{Flexibility}

The 'flexibility' dimension involves strategies that result in higher availability, ease of use, and access to instructional and informational materials by all students, considering its characteristics and limitations. It is recommended for its use, the observation of guidance that allow the continuous access, repeating of use, easy operation of system, and minimization of obstacles from technical limitations. Resources and instructional materials shall be made available in different ways, including redundant, for better adaptation to realities of different students.

\subsection{Feedback}

Finally, the 'feedback' dimension, is used in order to provide to the student the return of activities already performed, and may be presented with encouragement purposes, stimulus, explanation, confirmation, accuracy, reinforcement, correction, and other similar interactions in a virtual environment learning. Among these purposes, feedback shall be considered to motivate the student in the teaching-learning process. Feedback forms are contextual, and can be presented from their own computer systems and instructional materials, or from the authors, who can be the teacher, tutor, or students. One of the attributes of the dimension deals with the expected return time, which shall be as short and immediate as possible, to help on understanding and clarify of any doubts and difficulties. Automatic feedback from the computer system is in this context, although the customized ones, provided by teachers, have particular importance, depending on their quality. The student shall realize that there is a dialogue between them and the educational system.

\section{FINAL CONSIDERATIONS}

The experiences and modus operandi of the current online modality, realize that old challenges remain, such as the under-utilization of student involvement, and little incentive to authorship and online collaboration. The merely reactive support, which does not promote interactivity in learning, and the old didactic, linear or orthogonal design based on question or single answer, are realities to be modified. It is understood that the implementation of strategies based on pedagogical usability is consolidated as an alternative to provide higher quality in this modality. Authors that investigates the concept and related issues were presented, being 
explained the main referenced dimensions, notably control by the student, student's activity, collaborative and cooperative learning, orientation to purposes, applicability, value-added, motivation, value of prior knowledge, flexibility, and feedback. This is an important issue, bring contributions to adjustments and improvements in educational technologies and e-learning fields, and that need further research and empirical studies. It is recommended that further investigations are carried out, looking for dimensions, factors, emerging indicators, and not explicitly studied, as the use of social Internet (GRANIERI, 2006), and semantic web in the teaching-learning process, providing new guidance for the theme. Efforts for use of pedagogical usability in virtual environments of learning will influence positively the educational process. Applied studies can determine whether the strategies implemented by institutions that work with e-learning, are in correct routes, being crucial for resizing of researched environments, and a guiding element for future design in the field. The concept can be used as reference in the reconstruction of existing structures with respect to pedagogical aspects in virtual environments. It is understood that the implementation of these strategies enables greater autonomy for students, who will have greater co-participative capacity in the evaluation, and greater control to intervene positively in their personal development, consolidating their autonomy. The concept is presented as another opportunity to dissolve educational paradigms, and contribute to a better attitude to face the challenges of saturated information. This educational model, that makes use of active methodologies for teaching, provides participative structures for innovation, the use of emerging scenarios of network learning, and the use of educational technologies. This is the desired scenario for an authentic and centered learning in the student, in an online environment. In addition, its success permeates necessarily the commitment and effort of the teacher, which is also one of the beneficiaries in the process.

\section{REFERENCES}

1. ABREU, Ana Célia Bastos de. Avaliação de usabilidade em softwares educativos. 2010. 108f. Dissertação (Mestrado Integrado Profissional em Computação Aplicada). Universidade Estadual do Ceará (UECE). Fortaleza, 2010.

2. AGNER, Luiz Carlos Caldas. Inovação e qualidade do design na educação online: uma contribuição à usabilidade pedagógica. In: 15. Congresso Internacional ABED de Educação a Distância, 2009, Fortaleza, CE. Anais do 15 CIAED. São Paulo, SP: ABED, 2009.

3. ASSMANN, Hugo. Redes digitais e metamorfoses do aprender. Petrópolis: Vozes Editora, 2005.

4. BELINTANE, Claudemir. Por uma ambiência de formação contínua de professores. Cadernos de Pesquisa, São Paulo, n. 117, p. 177-193, 2002.

5. BOIKO, Bob. Content Management Bible. (2nd Edition). Wiley, 2004.

6. BRASIL, MEC. Decreto no 2.494, de 10 de Fevereiro de 1998. Regulamenta o Art. 80 da LDB (Lei n.o 9.394/96). Secretaria de Educação a Distância. Ministério da Educação. Brasília, 1998. Disponível em: <http://www.planalto.gov.br/ccivil_03/decreto/D2494.htm>. Acesso em: 29 out. 2014.

7. Decreto no 5.622, de 19 de Dezembro de 2005. Regulamenta o art. 80 da Lei no 9.394, de 20 de dezembro de 1996, que estabelece as diretrizes e bases da educação nacional. Secretaria de Educação a Distância. Ministério da Educação. Brasília, 1998. Disponível em: <http://www.planalto.gov.br/ccivil_03/_Ato2004-2006/2005/Decreto/D5622.htm\#art37>. 
Acesso em 29 ago. 2015.

8. CASTELLS, Manuel. A era da informação: economia, sociedade e cultura. In: A Sociedade em rede. V.1. São Paulo: Paz e Terra, 2000.

9. DIAS, Paulo. Da e-moderação à mediação colaborativa nas comunidades de aprendizagem. In Educação, Formação \& Tecnologias, V.1(1), p.4-10. 2008. Disponível em: <http://eft.educom.pt>. Acesso em: 29 mar. 2015.

10. DIAS, Paulo. Comunidades de educação e inovação na sociedade digital. In Educação, Formação \& Tecnologias, V.5 (2), p.4-10 [Online], 2012. Disponível em: <http://eft.educom.pt>. Acesso em: 20 fev. 2015.

11. GRANIERI, Giuseppe. Geração Blogue. Lisboa: Presença, 2006.

12. ISO 9241 Part 11. Ergonomic requirements for office work with visual display terminals, Part11: Guidance on usability. 1998.

13. MARTINS, Maria de Lourdes Oliveira. A Inter-relação Entre os Estilos de Aprendizagem, a Usabilidade de Design e a Usabilidade Pedagógica para a Construção da Interface de um Curso Universitário Online: Estudo de Caso. 2009. 182f. (Dissertação de Mestrado) - Erasmus Mundus - Euromime - Espanha, Portugal e França. 2009.

14. MATOS, Ecivaldo de Souza. Dialética da Interação Humano-Computador: tratamento didático do diálogo midiatizado. 2013. 269f. Tese (Doutorado em Educação). Universidade de São Paulo. São Paulo/SP, Brasil, 2013.

15. NIELSEN, Jakob. Evaluating Hypertext Usability. In D. H. Jonassen e H. Mandl (eds), Designing Hypermedia for Learning. Berlin: Springer-Verlag, 147-168. 1990.

16. NOKELAINEN, Petri. Conceptual Definition of the Technical and Pedagogical Usability Criteria for Digital Learning Material. In Proceedings of ED-MEDIA 2004: World Conference on Educational Multimedia, Hypermedia and Telecommunications, Lugano, Switzerland, p. 42494254. 2004.

17. NOKELAINEN, Petri. An empirical assessment of pedagogical usability criteria for digital learning material with elementary school students. Educational Technology \& Society, V.9 (2), p.178-197. 2006.

18. OLIVEIRA, Cleber Marques de. Usabilidade de design e usabilidade pedagógica a partir do olhar do aluno em EAD: uma análise comparativa entre dois ambientes virtuais de aprendizagem. Texto Livre: Linguagem e Tecnologia, [S.I.], v. 3, n. 1, p. 20-28, set. 2011.

19. OLIVEIRA, Lia Raquel Moreira. A comunicação educativa em ambientes virtuais: um modelo de design de dispositivos para o ensino-aprendizagem na universidade. 2004. 240f. Tese (Doutorado em Educação). Universidade do Minho, Braga/Portugal, 2004.

20. REITZ, Doris Simone. Avaliação do impacto da usabilidade técnica e pedagógica no desempenho de aprendizes em e-learning. 2009. 164f. Tese (Doutorado em Informática na Educação) - Centro Interdisciplinar de Novas Tecnologias na Educação. Universidade Federal do Rio Grande do Sul (UFRGS). Porto Alegre, 2009.

21. SALES JÚNIOR, Francisco Monteiro de; RAMOS, Maria Altina da Silva. Usabilidade técnica e Pedagógica em EAD: a percepção de alunos do IFRN. Anais do II Seminário Internacional de Educação a Distância (2. 2014: Natal, RN), 2014. 
22. SALES JÚNIOR, Francisco Monteiro de et al. Avaliação de ambientes virtuais de aprendizagem: um estudo comparativo entre formatos do Moodle de uma universidade. In: Challenges 2015: Meio século de TIC na Educação, Half a century of ICT in Education, 2015, Braga. ATAS DA IX CONFERÊNCIA INTERNACIONAL DE TIC NA EDUCAÇÃO. Braga: Universidade do Minho, Centro de Competência TIC do Instituto de Educação, v. 1., p.556-574, 2015a.

23. Technical and pedagogical usability in a virtual learning environment: A case study at the Federal Institute of Rio Grande do Norte Brazil. In: 2015 10th Iberian Conference on Information Systems and Technologies (CISTI), p. 1-4. Aveiro, 2015b.

24. SANTA ROSA, José Guilherme; STRUCHINER, Miriam. Design Participativo de um Ambiente Virtual de Aprendizagem de Histologia. Revista Brasileira de Pesquisa em Educação em Ciências, v. 10, p. 1-19, 2010. Disponível em: <http://revistas.if.usp.br/rbpec/article/view/5>. Acesso em: 27 fev. 2015.

25. SANTOS, Rosimeire Martins Régis dos. O Processo de colaboração na educação online: interação mediada pelas tecnologias de informação e comunicação. 2008. 174f. Dissertação (Mestrado em Educação) - Universidade Católica Dom Bosco, Campo Grande, 2008.

26. SILIUS, Kirsi; TERVAKARI, A-M.; Pohjolainen, Seppo. A Multidisciplinary Tool for the Evaluation of Usability, Pedagogical Usability, Accessibility and informational Quality of Web-based Courses. PEG2003- The Eleventh International PEG Conference: Powerful ICT for Teaching and Learning, 28 June - 1 July 2003 in St. Petersburg, Russia, 2003.

27. SSEMUGABI, Samuel. Usability Evaluation of a Web-based E-Learning Application: A Study of Two Evaluation Methods. 2006. 336f. Dissertação (Mestrado em Sistemas de Informação), University of South Africa, Unisa, South Africa, 2006.

28. SWELLER, John. Cognitive Load Theory: A Special Issue of educational Psychologist. LEA, Inc, 2003.

29. ULBRICHT, Vania Ribas et al. Usabilidade e acessibilidade em ambientes virtuais de ensino aprendizagem. In: José Guilherme SANTA ROSA. (Org.). Ergo Trip Design. 1ed.Rio de Janeiro: Rio Books, v. 1, p. 84-96. 2014.

30. VETROMILLE-CASTRO, Rafael. A usabilidade e a elaboração de materiais para o ensino de inglês mediado por computador. In: X Congresso Internacional de Educação a Distância ABED, 2003, Porto Alegre, 2003. 